University of Pittsburgh School of Law

Scholarship@PITT LAW

\title{
Brief of Amici Curiae Thirteenth Amendment Scholars in Support of Plaintiff-Appellee and Affirmance
}

\author{
William M. Carter Jr. \\ University of Pittsburgh School of Law, william.carter@law.pitt.edu \\ Dawinder S. Sidhu \\ University of Maryland at Shady Grove \\ Alexander Tsesis \\ Loyola University Chicago School of Law \\ Rebecca E. Zietlow \\ University of Toledo College of Law
}

Follow this and additional works at: https://scholarship.law.pitt.edu/fac_amici_briefs

Part of the Civil Rights and Discrimination Commons, Constitutional Law Commons, Gender and Sexuality Commons, Inequality and Stratification Commons, Law and Gender Commons, Law and Philosophy Commons, Law and Race Commons, Law and Society Commons, Race and Ethnicity Commons, Sexuality and the Law Commons, and the Social and Cultural Anthropology Commons

\section{Recommended Citation}

William M. Carter Jr., Dawinder S. Sidhu, Alexander Tsesis \& Rebecca E. Zietlow, Brief of Amici Curiae Thirteenth Amendment Scholars in Support of Plaintiff-Appellee and Affirmance, U.S. Court of Appeals for the Tenth Circuit, No. 12-2040 (2012).

Available at: https://scholarship.law.pitt.edu/fac_amici_briefs/1

This Amici Brief is brought to you for free and open access by the Faculty Publications at Scholarship@PITT LAW. It has been accepted for inclusion in Amici Briefs by an authorized administrator of Scholarship@PITT LAW. For more information, please contact leers@pitt.edu, shephard@pitt.edu. 
No. $12-2040$

\title{
IN THE UNITED STATES COURT OF APPEALS
} FOR THE TENTH CIRCUIT

\author{
UNITED STATES, \\ Plaintiff-Appellee, \\ $V$. \\ WILLIAM HATCH, \\ Defendant-Appellant.
}

ON APPEAL FROM THE UNITED STATES DISTRICT COURT FOR THE DISTRICT OF NEW MEXICO

\section{BRIEF OF AMICI CURIAE THIRTEENTH AMENDMENT SCHOLARS IN SUPPORT OF PLAINTIFF-APPELLEE AND AFFIRMANCE}

GEORGE BACH

Counsel of Record

DAWINDER S. SIDHU

1117 Stanford NE, MSC11 6070

1 University of New Mexico

Albuquerque, NM 87131

(505) 277-2146

August 1, 2012
WiLliam M. CARTER, JR.

3900 Forbes Avenue

Pittsburgh, PA 15260

(412) 648-1401

AleXAnder Tsesis

25 E. Pearson Street

Chicago, IL 60611

(312) 915-7929

REBECCA E. ZIETLOW

2801 West Bancroft, MS 507

Toledo, $\mathrm{OH}$

(419) 530-2872 


\section{TABLE OF CONTENTS}

TABLE OF AUTHORITIES ............................................. ii

INTERESTS OF AMICI CURIAE..................................... 1

SUMMARY OF ARGUMENT ........................................ 3

ARGUMENT: DISTRICT COURT PROPERLY DENIED APPELLANT'S MOTION TO DISMISS THE INDICTMENT FOR

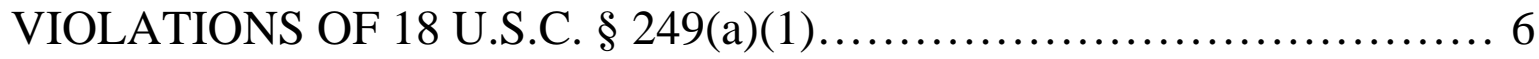

I. The Historical Record and Supreme Court Caselaw Make Clear that Congress Enjoys Broad Authority to Enforce the Thirteenth Amendment.................................................... 6

II. Section 249(a)(1) is Governed by the "Rationality" Standard of Jones.

A. The Constitutionality of 18 U.S.C. § 249(a)(1) Must be Reviewed Under Jones....................................... 10

B. The District Court Correctly Held that City of Boerne Does Not Apply to 18 U.S.C. § 249(a)(1)............................ 12

III. Congress Validly Enacted 18 U.S.C. § 249(a)(1) Pursuant to the Thirteenth Amendment............................................. 18

A. 18 U.S.C. § 249(a)(1) Easily Satisfies Jones................... 18

B. As 18 U.S.C. § 249(a)(1) Was Passed Pursuant to an Enumerated Constitutional Power, It Does Not Offend Federalism Principles.

IV. As the Thirteenth Amendment Applies to all Badges and Incidents of Slavery Inflicted Upon Any Person of Any Race, 18 U.S.C. $\S$ 249(a)(1) Does Not Implicate Strict Scrutiny or Violate Equal Protection Principles............................................ 23

CONCLUSION ........................................................ 30 


\section{TABLE OF AUTHORITIES}

\section{Cases}

CBOCS West, Inc. v. Humphries, 553 U.S. 442 (2008).........................16

Civil Rights Cases, 109 U.S. 3 (1883)............................... passim

City of Boerne v. Flores, 521 U.S. 507 (1997)...........................passim

Domino’s Pizza, Inc. v. McDonald, 546 U.S. 470 (2006).......................18

Jones v. Alfred H. Mayer Co., 392 U.S. 409 (1968).......................passim

Jones v. R.R. Donnelley \& Sons Co., 541 U.S. 369 (2004).....................18

McCulloch v. Maryland, 17 U.S. (4 Wheat.) 316 (1819)................11, 19, 21

McDonald v. Sante Fe Trail Transp. Co., 427 U.S. 273 (1976)..................28

Patterson v. McLean Credit Union, 491 U.S. 164 (1989).......................18

Plessy v. Ferguson, 163 U.S. 537 (1896).................................19

Runyon v. McCrary, 427 U.S. 160 (1976)............................. 17

Slaughter-House Cases, 83 U.S. (16 Wall.) 36 (1873)........................ 7

United States v. Beebe, et al., 807 F.Supp.2d 1045 (D. N.M. 2011)......3, 4, 13, 27

United States v. Bob Lawrence Realty, Inc., 474 F.2d 115 (5th Cir. 1973), cert.

denied, 414 U.S. 826 (1973).............................................11

United States v. Comstock, 560 U.S. _ _ 130 S.Ct. $1949(2010) \ldots \ldots \ldots \ldots \ldots \ldots . .22$

United States v. Hampshire, 95 F.3d 999 (10th Cir. 1996), cert. denied, 519 U.S.

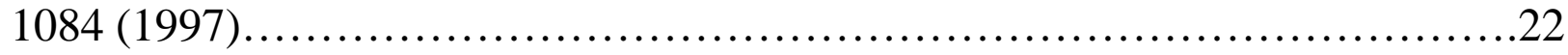

United States v. Lopez, 514 U.S. 549 (1995)................................22 
United States v. Nelson, 277 F.3d 164 (2nd Cir. 2002)

$.10,15$

\section{Constitutional and Statutory Provisions}

18 U.S.C. $\S 249(a)(1)$ .passim

1867 Anti-Peonage Act, Ch. 187, 14 Stat. 546 (1867) (codified as amended at 18 U.S.C. §1581 (2006) and 42 U.S.C. §1994 (2006))...

An Act to Protect Persons of Foreign Birth Against Forcible Constraint or Involuntary Servitude, ch. 464, 18 Stat. 251 (1874) (codified as amended at 18

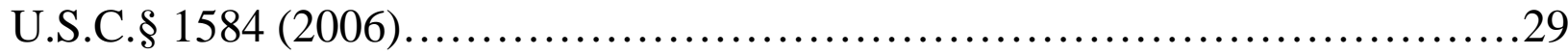

Civil Rights Act of 1866, ch. 31, 14 Stat. 27 (codified as amended at 18 U.S.C. § 242 and 42 U.S.C. $\S \S 1981$ 1982)....................................., 17

U.S. Const. Art. I. § 8, cl. 3...........................................4

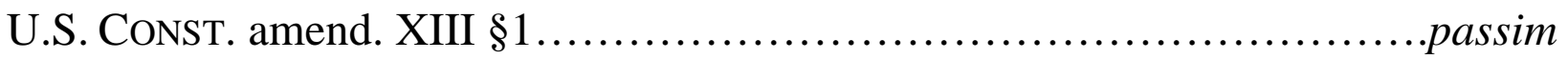

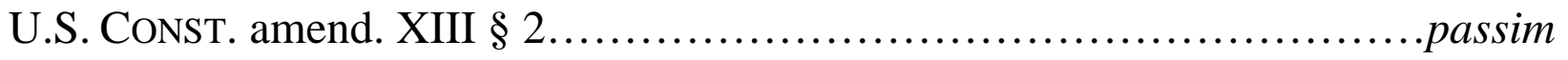

U.S. Const. amend. XIV ...........................................passim

\section{Legislative Materials}

Cong. Globe, 36th Cong., 1st Sess. (1860)...............................28

Cong. Globe, 38Th Cong., 1st Sess. (1864).................................25

CONG. GloBE, 38Th Cong., 2ND SeSs. (1865)..........................24, 28

Cong. Globe, 39th Cong., 1st Sess. (1865-66)........................... 11

Cong. Globe, 42ND CONG., 1st Sess. (1871).............................11

Cong. GloBe, 42ND Cong., 2ND SESS. (1872)..............................25 


\section{Other Authorities}

Akhil Reed Amar, Plessy v. Ferguson and the Anti-Canon, 39 PePp. L. Rev. 75 (2011)

G. Sidney Buchanan, The Quest for Freedom: A Legal History of the Thirteenth Amendment, 12 Hous. L. REV. 1069 (1975).

William M. Carter, Jr., A Thirteenth Amendment Framework for Combating Racial Profiling, 39 HarV. Civil Rights-Civil LiBerties L. ReV. 17 (2004)........23, 26

William M. Carter, Jr., Race, Rights, and the Thirteenth Amendment: Defining the Badges and Incidents of Slavery, 40 U.C. DAVIS L. REV. 1311 (2007).............26

William M. Carter, Jr., The Thirteenth Amendment, Interest Convergence, and the Badges and Incidents of Slavery, 71 MD. L. REV. 21 (2012)....................23

Michael Kent Curtis, The Klan, the Congress, and the Court, 11 U. PA. J. Const. L. 1381 (2009). .27

James A. Garfield, Oration Delivered at Ravenna, Ohio July 4, 1865, in 1 THE WORKS OF JAMES ABRAM GARFIELD 86 (Burke A. Hinsdale ed., 1882)...........7, 8

R.A. Lenhardt, Understanding the Mark: Race, Stigma, and Equality in Context, 79 N.Y.U. L. REV. 803 (2004)............................................19

Darrell A. H. Miller, White Cartels, the Civil Rights Act of 1866 and the History of Jones v. Alfred H. Mayer Co., 77 FordHAM L. REV. 999 (2008)..............26, 29

John E. Nowak, The Rise and Fall of Supreme Court Concern for Racial Minorities, 36 WM. \& MARY L. REV. 345 (1995).............................17

George Rutherglen, State Action, Private Action, and the Thirteenth Amendment, 94 VA. L. REV. 1367 (2008).............................................. 7

Dawinder S. Sidhu, A Constitutional Remedy for Urban Poverty, 62 DEPAUL L. REV. * (forthcoming, 2012), available at: http://ssrn.com/abstract=1872184........10

Alexander Tsesis, The Problem of Confederate Symbols: A Thirteenth Amendment Approach, 75 TEMP. L. REV. 539 (2002) ....................................20 
Alexander Tsesis, Gender Discrimination and the Thirteenth Amendment, 112 COLUM. L. REV. * (forthcoming 2012) ...................................8

Rebecca E. Zietlow, Free At Last! Anti-Subordination and the Thirteenth Amendment, 90 B.U. L. REV. 255 (2010)....................................29 


\section{INTERESTS OF AMICI CURIAE ${ }^{1}$}

Amici are professors of law whose expertise focuses primarily or at least substantially on the Thirteenth Amendment to the U.S. Constitution. Amici are united in their belief that the Thirteenth Amendment should be construed so as to give full meaning and practical effect to its protections, and that the Thirteenth Amendment remains a vital instrument of liberty and an essential shield against targeted racial violence in contemporary America.

Amici, prominent scholars in this area of constitutional law, have published a number of academic works -- in law review, essay, and book format -- on the meaning, scope, and modern applicability of the Thirteenth Amendment. Amici therefore have significant professional and intellectual interest in ensuring that the Court properly interprets the Thirteenth Amendment. Moreover, two law review articles, written by one of the amici law professors, have been cited and mischaracterized by Appellant. Amici therefore possess additional professional and scholarly interest in correcting Appellant's representation of those articles and thereby ensuring that the Court properly understands the arguments contained in them.

${ }^{1}$ Pursuant to Federal Rule of Appellate Procedure 29(c)(5), counsel for amici declare that no counsel for either party authored this brief in whole or in part; no party or no party's counsel contributed money that was intended to fund preparing or submitting the brief; and that no person -- other than the amici, its members, or its counsel -- contributed money that was intended to fund preparing or submitting the brief. 
Amici submit this brief for these purposes, and to illuminate matters within their expertise and to enrich the Court's understanding of the Thirteenth Amendment.

Amici names and their institutional affiliations, which are listed for identification reasons only, are as follows:

- William M. Carter, Jr., Dean, University of Pittsburgh School of Law

- Dawinder S. Sidhu, Assistant Professor of Law, University of New Mexico School of Law

- Alexander Tsesis, Associate Professor of Law, Loyola University, Chicago, School of Law

- Rebecca E. Zietlow, Charles W. Fornoff Professor of Law and Values, University of Toledo College of Law 


\section{SUMMARY OF ARGUMENT}

This case owes its existence to troubling facts, and this appeal to Appellant's mistaken understanding of the Thirteenth Amendment. With respect to the facts, Appellant and two other white men, Paul Beebe and Jesse Sanford, assaulted a developmentally disabled Native American man, and subjected the victim to this violent mistreatment specifically because he is not white. For this, Appellant, Beebe, and Sanford were indicted for violating the Hate Crimes Prevention Act, 18 U.S.C. § 249(a)(1), which makes it a crime to "willfully cause[] bodily injury to any person or," through the use of certain instruments, "attempt[] to cause bodily injury to any person, because of the actual or perceived race, color, religion, or national origin of any person[.]” As the parties agree, Section 249(a)(1) was passed by Congress pursuant to its enforcement power under Section Two of the Thirteenth Amendment, U.S. Const. amend. XIII § 2. See Appellant’s Br. at 8 ("The legislative history of the [Act] reflects Congress's understanding that it was acting under the Thirteenth Amendment in enacting § 249(a)(1)[.]”); Defs.' Mot. to Dismiss, United States v. Beebe, et al., No. 1:10-CR-03104-BB, at 2 (D. N.M. May 20, 2011) ("The [Act] findings cite the Thirteenth Amendment as authority for the provisions in § 249(a)(1)[.]”); U.S. Resp. Br., United States v. Beebe, et al., No. 1:10-CR-03104-BB, at 5 (D. N.M. June 20, 2011) (“As acknowledged by the 
defendants, [§ 249(a)(1)] was enacted pursuant to Congress’s Thirteenth

Amendment authority to eradicate badges and incidents of slavery.”). ${ }^{2}$

Defendants moved to dismiss the indictments on the theory that Section 249(a)(1) exceeds Congress's Thirteenth Amendment enforcement power and is inconsistent with the Equal Protection guarantee of the Fifth Amendment. The U.S. District Court for the District of New Mexico denied the motion, holding that "the Thirteenth Amendment, Section Two, provided Congress with ample authority to pass section 249(a)(1).” United States v. Beebe, et al., 807 F.Supp.2d 1045, 1047 (D. N.M. 2011); see also id. at 1053 ("The facts involved in this case are not near any grey area of section 249's constitutionality, but rather fall well within the scope of actions that the framers empowered Congress to ban in passing Section Two of the Thirteenth Amendment."). It further concluded that as "the statute applies to crimes against victims of all races... victimized on the basis of race," "the statute addresses this race-related issue in a racially neutral manner" and therefore "raises no equal protection issue." Id. at 1058.

With respect to this appeal, Appellant renews his constitutional objections. Appellant contends in particular that Section 249(a)(1) encroaches on States' rights

${ }^{2}$ The Act contains an additional criminal offense, 18 U.S.C. § 249(a)(2), which Congress passed pursuant to its Commerce Clause power, see U.S. ConsT., Art. I. § 8, cl. 3. As there is no dispute that Appellant was indicted for violating Section 249(a)(1) and not Section 249(a)(2), and as neither of the questions presented by Appellant address the Commerce Clause, amici will focus only on Congress's authority under the Thirteenth Amendment to pass Section 249(a)(1). 
and is unnecessary due to States' prosecution of bias-motivated crimes, and that therefore this statutory provision cannot stand as valid Thirteenth Amendment legislation under either the City of Boerne v. Flores, 521 U.S. 507 (1997) standard that Appellant prefers, or the Jones v. Alfred H. Mayer Co., 392 U.S. 409 (1968) standard that the District Court, United States, and amici agree applies. Appellant additionally claims that the Thirteenth Amendment does not authorize Congress to protect white victims, and that therefore Section 249(a)(1) validly extends to only certain races, embodies a racial classification as a result, and does not survive the requisite strict scrutiny equal protection standard.

Amici, leading scholars on the Thirteenth Amendment, believe that Section 249(a)(1) falls well within Congress's Thirteenth Amendment enforcement power and is plainly constitutional. In this brief, amici seek to describe the broad scope of Congress's Thirteenth Amendment enforcement power; argue that Thirteenth Amendment legislation must be reviewed under the deferential "rationality" standard of Jones; explain that because Section 249(a)(1) is grounded in a specific enumerated power, it neither infringes on States' sovereignty nor does it stem from or give rise to any "federal police power"; and clarify that, because the Thirteenth Amendment empowers Congress to eradicate the badges and incidents of slavery as to any racial group, including whites, it does not contain a racial classification and thereby does not trigger strict scrutiny or any Equal Protection concerns. 
As the District Court's order is consistent with these principles, and as Appellant's challenges to the order are not supported by a proper interpretation of the Thirteenth Amendment, amici urge the Court to affirm the decision below.

\author{
ARGUMENT \\ DISTRICT COURT PROPERLY DENIED APPELLANT'S \\ MOTION TO DISMISS THE INDICTMENT FOR VIOLATIONS OF 18 \\ U.S.C. § 249(a)(1)
}

\title{
I. THE HISTORICAL RECORD AND SUPREME COURT CASELAW MAKE CLEAR THAT CONGRESS ENJOYS BROAD AUTHORITY TO ENFORCE THE THIRTEENTH AMENDMENT
}

The Thirteenth Amendment declares that "Neither slavery nor involuntary servitude, except as a punishment for crime whereof the party shall have been duly convicted, shall exist within the United States, or any place subject to their jurisdiction.” U.S. ConsT. amend. XIII §1. “The amendment is not a mere prohibition of State laws establishing or upholding slavery, but an absolute declaration that slavery or involuntary servitude shall not exist in any part of the United States.” Civil Rights Cases, 109 U.S. 3, 20 (1883). The Thirteenth Amendment further empowers Congress "to enforce this article by appropriate legislation.” U.S. CONST. amend. XIII § 2. Historical sources and Supreme Court pronouncements indicate that Section Two of the Amendment gives Congress broad authority to enforce the substantive, robust command of Section One. 
As a reflection of its expansive scope, Congress may, pursuant to the Thirteenth Amendment, regulate private conduct and not just state action. Jones, 392 U.S. at 443-44 (1968) (holding that the Thirteenth Amendment allows Congress to prevent private acts of discrimination); Runyon v. McCrary, 427 U.S. 160, 172-73 (1976) (same). Accordingly, "[t]he Thirteenth Amendment stands out in the Constitution as the only provision currently in effect that directly regulates private action.” See George Rutherglen, State Action, Private Action, and the Thirteenth Amendment, 94 VA. L. ReV. 1367, 1370 (2008). Moreover, Thirteenth Amendment protections are not only absolute, but also universal. The Thirteenth Amendment's prohibitions extend to all races, not just African-Americans. See Slaughter-House Cases, 83 U.S. (16 Wall.) 36, 72 (1873).

Those prohibitions themselves are broad. While Section One of the Amendment speaks in terms of slavery and involuntary servitude, from the days of ratification there was a consensus that the Amendment is about much more. In the words of the Congressman and future President of the United States, James A. Garfield, liberty is no more than "a bitter mockery" and "a cruel delusion" if it is merely the freeing of slaves from the bondage without the federal protection against private militias, such as the Ku Klux Klan. James A. Garfield, Oration Delivered at Ravenna, Ohio July 4, 1865, in 1 THE Works OF JAMES ABRAM GARFIELD 86 (Burke A. Hinsdale ed., 1882). Indeed, during the congressional 
debates on the Thirteenth Amendment, those congressmen who supported its passage onto the States for ratification repeatedly spoke about how modification to the Constitution would allow for congressionally led civil rights reform.

Representative Isaac N. Arnold, who was President Lincoln’s close confidant, asserted that the Thirteenth Amendment would establish "equality before the law . . . to be the great cornerstone" of the United States government. In a similar vein, Senator John Sherman of Ohio, who had his hand on the pulse of federal power later becoming Secretary of the Treasury and then Secretary of State, asserted that the enforcement provision was "an express grant of power to Congress to secure . . . liberty by appropriate legislation.” CONG. GLOBE, 39TH CONG., 1st SeSS. 41 (1865).

Passage of the Civil Rights Act of 1866 only a year after ratification of the Thirteenth Amendment provides one of the best indicators of the Thirteenth Amendment augmented federal authority to pass civil rights laws. The overwhelming majority of Congressmen who passed the Amendment on to the states for ratification also voted for the Act of 1866. See Alexander Tsesis, Gender Discrimination and the Thirteenth Amendment, 112 ColuM. L. REV. * (forthcoming 2012) (providing a complete comparison of congressional voting records on the Thirteenth Amendment and Civil Rights Act of 1866). The protections of contractual, ownership, and litigation rights in the Civil Rights Act 
of 1866 were only the beginnings of Congress's uses of Thirteenth Amendment authority. Civil Rights Act of 1866, ch. 31, 14 Stat. 27 (codified as amended at 18 U.S.C. § 242 and 42 U.S.C. $\S \S 1981$ 1982).

The Supreme Court's Thirteenth Amendment jurisprudence similarly recognizes the broad meaning of the Amendment's prohibitions and Congress's attendant significant authority to enforce the Amendment. The Amendment not only "nullif[ied]" slavery, the Court held, but also "clothed Congress with power to pass all laws necessary and proper for abolishing all badges and incidents of slavery in the United States[.]” Civil Rights Cases, 109 U.S. at 20. The Court clarified in Jones that Congress has the authority "rationally to determine what are the badges and the incidents of slavery, and the authority to translate that determination into effective legislation.” Jones, 392 U.S. at 440; see also G. Sidney Buchanan, The Quest for Freedom: A Legal History of the Thirteenth Amendment, 12 Hous. L. REV. 1069, 1071 (1975) (“Congress, in defining badges of slavery, can expand the self-executing force of the thirteenth amendment, that is, Congress can define given conduct as constituting a badge of slavery even though such conduct would not be prohibited by the thirteenth amendment, unaided by congressional legislation.”). Accordingly, as Judge Guido Calabresi has explained, “Congress’s enforcement power under Section Two of the Thirteenth 
Amendment extends well beyond the scope of the direct prohibitions contained in

Section One.” United States v. Nelson, 277 F.3d 164, 185 n. 20 (2nd Cir. 2002).

Based on the above, it is beyond doubt that Congress's enforcement power under the Thirteenth Amendment is quite significant. ${ }^{3}$

\section{SECTION 249(A)(1) IS GOVERNED BY THE “RATIONALITY” STANDARD OF JONES}

\section{A. THE CONSTITUTIONALITY OF 18 U.S.C. § 249(a)(1) MUST BE REVIEWED UNDER JONES}

Congress relied on its robust Thirteenth Amendment power to enact 18

U.S.C. § 249(a)(1). Challenges to laws passed pursuant to the Thirteenth

Amendment are reviewed under the standard set forth by the Supreme Court in

Jones. Accordingly, the Court must turn to Jones in order to assess the

constitutionality of $\S 249(\mathrm{a})(1)$.

In Jones, the Supreme Court limited its review to whether a statute passed

pursuant to the Thirteenth Amendment is rationally related to a necessary and

proper method for ending existing incidents and badges of slavery and involuntary

servitude. Jones, 392 U.S. at 439 (quoting Civil Rights Cases, 109 U.S. at 20

(holding that the Section Two of the Thirteenth Amendment empowers Congress

${ }^{3}$ For a discussion of other aspects of the meaning of the Thirteenth

Amendment, including the absence of any intent requirement and the view that the Amendment entitles all individuals, not just African-Americans, to a minimal threshold of liberty, see Dawinder S. Sidhu, A Constitutional Remedy for Urban Poverty, 62 DePaul L. REV. * (forthcoming, 2012), available at: http://ssrn.com/abstract=1872184, *43-48. 
'to pass all laws necessary and proper for abolishing all badges and incidents of slavery in the United States.”)). The Court stated that, "Surely Congress has the power under the Thirteenth Amendment rationally to determine what are the badges and the incidents of slavery, and the authority to translate that determination into effective legislation.” 392 U.S. at 440.

This formulation is deferential. Members of the Reconstruction Congress repeatedly invoked the deferential test for congressional power provided in McCulloch v. Maryland, 17 U.S. (4 Wheat.) 316 (1819), to illustrate the meaning of the word "appropriate" in Section Two. See, e.g., Cong. Globe, 39th Cong., 1ST Sess. 1115, 1118 (1866) (statement of Rep. Wilson); CoNG. GLOBE, 42ND Cong., 1st SESS. 686, 695 (1871) (statement of Sen. Thurman). As Senator Lyman Trumbull explained, “what the 'appropriate legislation’ is, is for Congress to determine, and nobody else.” Cong. GLOBE, 39TH Cong., 1st SESs. 39, 43 (1865).

Jones is consistent with this original understanding that Section Two empowers Congress with substantial autonomy to enforce the amendment, and invokes a standard of judicial deference. See United States v. Bob Lawrence Realty, Inc., 474 F.2d 115, 120 (5th Cir. 1973), cert. denied, 414 U.S. 826 (1973) ("the mandate of Jones is clear. This Court will give great deference, as indeed it must, to the congressional determination that [the statutory provision under review] 
will effectuate the purpose of the Thirteenth Amendment by aiding in the

elimination of the 'badges and incidents of slavery in the United States.'”) (quoting Jones, 392 U.S. at 439).

It has long been a canonical doctrine that Congress's authority under the Thirteenth Amendment is similar to the legislative power under the Necessary and Proper Clause. The Court in Jones recognized that under the Thirteenth Amendment Congress could pass any laws "necessary and proper” for ending any remaining badges of slavery. Jones, 392 U.S. at 439. That conclusion was predicated on precedent that is now over one hundred years old, holding that Congress has the "power to pass all laws necessary and proper for abolishing all badges and incidents of slavery in the United States.” Civil Rights Cases, 109 U.S. at 20 .

\section{B. THE DISTRICT COURT CORRECTLY HELD THAT CITY OF BOERNE DOES NOT APPLY TO 18 U.S.C. § 249(a)(1)}

Appellant urges this Court to reject the rational basis approach of Jones, and adopt the Fourteenth Amendment congruence and proportionality test of City of Boerne. However, Appellant's formulation misconstrues City of Boerne. The Supreme Court has never extended nor suggested that the congruence and proportionality test of City of Boerne applies to evaluations of Congress's exercise of its Thirteenth Amendment enforcement power. The City of Boerne holding is inapplicable to any other constitutional grant of legislative authority other than the 
Fourteenth Amendment. The concerns underlying City of Boerne's Fourteenth Amendment holding are not present with respect to Thirteenth Amendment legislation, and the Thirteenth and Fourteenth Amendments are analytically distinct. Indeed, the Supreme Court in a post-City of Boerne ruling invoked the Jones test. Finally, grafting the City of Boerne standard on the Thirteenth Amendment would undermine other civil rights legislation.

In the 1997 case of City of Boerne, the Court imposed restrictions on congressional power to enforce the Fourteenth Amendment, pursuant to Section Five of that Amendment. City of Boerne, 521 U.S. 507. The Court held that the Section Five power was limited to legislation that is congruent and proportional to a violation of Section One of that Amendment. Id. at 519-20. As the District Court below noted, City of Boerne only considered the Fourteenth Amendment enforcement power, and gave no indication that its congruence and proportionality test would apply to any of the enforcement clauses in any other amendments. Beebe, 807 F. Supp.2d at 1049.

In City of Boerne, the Court struck down a provision of the Religious Freedom Restoration Act, which regulated state governments, because it was not congruent and proportional to the state's violation of the Free Exercise clause of the First Amendment. City of Boerne, 521 U.S. at 532. In its ruling, the Court stated that if Congress's power to enforce the Fourteenth Amendment is too broad, 
it would threaten state autonomy and principles of separation of powers. Id. Neither concern justifies applying the same restrictive test to the Section Two power to enforce the Thirteenth Amendment.

Congressional enforcement of the Thirteenth Amendment simply does not have the same implications to state autonomy as enforcement of the Fourteenth Amendment. The scope of the Section Five power directly affects the state because Congress can only use that power to regulate state action. See Civil Rights Cases, 109 U.S. 3 (1883). By contrast, much of the legislation enforcing the Thirteenth Amendment, including that at issue in this case, regulates private, and not state, action. Thus, unlike legislation enforcing the Fourteenth Amendment, Section Two based legislation does not have any more impact on state autonomy than any other federal legislation.

Similarly, the City of Boerne Court's concern about separation of powers does not justify restricting the Section Two power. In City of Boerne, the Court was confronted with a statute in which Congress had attempted to define the Fourteenth Amendment differently from the way that the Court had defined it, intruding on the proper function of "the Judicial Branch ... to say what the law is." City of Boerne, 521 U.S. at 536. By contrast, the Court has never reached a definitive holding regarding the meaning of the Thirteenth Amendment's prescription of the badges and incidents of slavery. Indeed, the meaning of the 
direct prohibitions of Section One of the Amendment "has almost never been addressed directly by the courts, in the absence of specific congressional legislation enacted.” Nelson, 277 F.3d at 185 n. 20. Therefore, legislation defining the badges or incidents of slavery cannot be said to conflict with any prior determination of that meaning by the Court. Thus, concerns of separation of powers also do not justify extending the congruence and proportionality test to Congress' Section Two power.

Moreover, though the Thirteenth Amendment and Fourteenth Amendments have their origins in post-Civil War attempts to restore meaningful liberty to all Americans, particularly African-Americans, the two are distinct. The Thirteenth Amendment, unlike the Fourteenth, contains a positive mandate (i.e., that slavery shall no longer exist in the United States). The Supreme Court has found that the Thirteenth Amendment's Section Two is, unlike the Fourteenth Amendment's Section Five, broad and entitled to significant deference. The Thirteenth Amendment, unlike the Fourteenth, has no state action requirement and thus Congress has Thirteenth Amendment authority to pass legislation directly affecting private conduct. Accordingly, to superimpose Fourteenth Amendment jurisprudence unto the Thirteenth Amendment presumes away the analytical distinction between the Fourteenth and Thirteenth Amendments that the Court has always taken to be a given. If the Court were to follow Appellant's suggestion to 
graft the congruence and proportionality test from the Fourteenth Amendment onto the Thirteenth Amendment area, it would be deviating from over a hundred years of precedents. The Court's unwavering analytical contrast between the Thirteenth and Fourteenth Amendments' Enforcement Clauses means that the congruence and proportionality test does not apply to 18 U.S.C. $\S 249(a)(1)$, whose passage was predicated on Thirteenth Amendment powers, but not the Fourteenth Amendment.

Even after City of Boerne, the Court has adhered to its ruling in Jones and continued to defer to the Section Two power. In the 2008 case of CBOCS West, Inc. v. Humphries, the Court held that 42 U.S.C. §1981, a provision of the 1866 Civil Rights Act which prohibits race discrimination in contracts, encompasses a complaint of retaliation against a person who has complained about race discrimination against another employer. 553 U.S. 442, 446 (2008). The Court broadly interpreted the meaning of $§ 1981$, relying on stare decisis and congressional deference. Id. at 449-52. The Court's ruling in CBOCS indicates that it did not believe that the City of Boerne standard extended to the Section Two power.

Finally, Appellant’s proposed test for reviewing 18 U.S.C. § 249(a)(1) would have negative repercussions as to §1981 and civil rights law more generally. If the congruence and proportionality test were to be applied to the interpretation of statutes passed pursuant to Thirteenth Amendment enforcement authority, it might 
signal the demise of 42 U.S.C. §§ 1981 and 1982. 42 U.S.C. §1981 (2006)

(originally enacted as Civil Rights Act of 1866, ch. 31, 14 Stat. 27, 27) (“All persons within the jurisdiction of the United States shall have the same right in every State and Territory to make and enforce contracts, to sue, be parties, give evidence, and to the full and equal benefit of all laws and proceedings for the security of persons and property as is enjoyed by white citizens, and shall be subject to like punishment, pains, penalties, taxes, licenses, and exactions of every kind, and to no other.”); 42 U.S.C. §1982 (originally enacted as part of the Civil Rights Act of 1866, ch. 31, 14 Stat. 27, 27) (“All citizens of the United States shall have the same right, in every State and Territory, as is enjoyed by white citizens thereof to inherit, purchase, lease, sell, hold, and convey real and personal property.”); John E. Nowak, The Rise and Fall of Supreme Court Concern for Racial Minorities, 36 WM. \& MARY L. REV. 345, 388 (1995) (mentioning that Congress passed $\S \S 1981$ and 1982 based on its Thirteenth Amendment grant of authority).

The Supreme Court has long held that $\S \S 1981$ and 1982 are rationally related to Congress's Thirteenth Amendment authority without ever reviewing their congruence nor proportionality to the discriminatory harms they address. Jones, 392 U.S. at 440-41; Runyon, 427 U.S. at 170 (adopting the Jones test of whether a "prohibition was within Congress's power under Section 2 of the 
Thirteenth Amendment 'rationally to determine what are the badges and the incidents of slavery, and... to translate that determination into effective legislation”' (quoting Jones, 392 U.S. at 440)). The Court has repeatedly applied § 1981 in the context of employment discrimination. Patterson v. McLean Credit Union, 491 U.S. 164, 175-76 (1989), superseded by statute on other grounds Jones v. R.R. Donnelley \& Sons Co., 541 U.S. 369, $372-73$ (2004); Domino’s Pizza, Inc. v. McDonald, 546 U.S. 470, 476 (2006). In reviewing statutes passed pursuant to the Thirteenth Amendment, the congruence and proportionality test would add a layer of judicial review that would increase the burden of proof for employment discrimination plaintiffs beyond anything ever recognized. Therefore, Appellant's suggested test could have a negative impact far outside the specific provisions of 18 U.S.C. § 249(a)(1).

For all of these reasons, this Court should continue to adhere to the deferential standard of Jones and reject Appellant's attempt to extend City of Boerne to the Thirteenth Amendment Section Two power.

\section{CONGRESS VALIDLY ENACTED 18 U.S.C. § 249(A)(1) PURSUANT TO THE THIRTEENTH AMENDMENT}

\section{A. 18 U.S.C. § 249(A)(1) EASILY SATISFIES JONES}

In Jones, the Supreme Court pointed out that, Congress is empowered to rationally determine laws that are "necessary and proper" for eradicating the badges and incidents of slavery. 392 U.S. at 440. The Court has construed 
“necessary and proper” in light of Chief Justice Marshall’s guiding principle in McCulloch v. Maryland that "necessary and proper" is constitutionally synonymous, or at least analogous, to "appropriate," which is the language used in the Section Two of the Thirteenth Amendment. McCulloch, 17 U.S. at 356. The facts of this case exemplify the fact that Congress's determination that 18 U.S.C. § 249(a)(1) is necessary and proper for the purpose of eliminating the badges and incidents of slavery comfortably surpasses Jones's modest threshold of rationality.

It is undisputed that the defendants in this action branded the victim, a developmentally Native American man. Branding is a quintessential badge and incident of slavery. In his famous dissent in Plessy v. Ferguson, Justice Harlan equated "badge[s] of servitude" with that which "practically... puts the brand of servitude and degradation upon a large class of our fellow-citizens, our equals before the law.” 163 U.S. 537, 562 (1896) (Harlan, J., dissenting). As a preeminent constitutional law scholar explains, "When [Justice Harlan] uses the word 'brand,"” he is "referring to how human beings under slavery were branded like cattle.” Akhil Reed Amar, Plessy v. Ferguson and the Anti-Canon, 39 PePP. L. REv. 75, 86 (2011). It is beyond question that branding was a regular mechanism used by overseers to subjugate slaves. See R.A. Lenhardt, Understanding the Mark: Race, Stigma, and Equality in Context, 79 N.Y.U. L. REv. 803, 815 (2004) ("Brands were used as a way of identifying African slaves as human property up 
until the latter part of the eighteenth century and as a method of punishment well into the nineteenth century," "were used to demarcate slave or outsider status," and undoubtedly and directly carry “racial stigma”). Frederick Douglass, for example, noted that the skin of a slave was "laid bare... the iron was then delivered red hot (sensation), and applied to the quivering flesh, imprinting upon it the name of the monster who claimed the slave.” Amar at 86 n.99 (citation omitted).

The victim in this action was not only branded by his white captors because he was not-white, but was branded with a swastika -- an undeniable symbol of white supremacy and of racial hate. The meaning of the swastika brings the branding of this particular case well within the type of racial domination and intimidation contemplated by the Thirteenth Amendment. See Alexander Tsesis, The Problem of Confederate Symbols: A Thirteenth Amendment Approach, 75 TEMP. L. REV. 539, 548 (2002) (identifying swastikas as among the "threatening signs" that "have historical connotations that draw upon and enhance the 'badges' and 'symbols' of servitude, discrimination, oppression, and persecution.”).

Appellant's concern that 18 U.S.C. § 249(a)(1) reaches every conceivable harm or form of discrimination, or that a decision upholding the constitutionality of the statutory provision will open the door to unlimited congressional action, is unfounded. Section 249(a)(1) as applied to this case reaches racial conduct that was central to slavery and that conveys white dominance and racial hatred. 
Accordingly, there is ample support, particularly in the context of this case, for the District Court's holding that it was rational for Congress to enact 18 U.S.C. § 249(a)(1) pursuant to its Thirteenth Amendment enforcement power. ${ }^{4}$

\section{B. AS 18 U.S.C. $§$ 249(A)(1) WAS PASSED PURSUANT TO AN ENUMERATED CONSTITUTIONAL POWER, IT DOES NOT OFFEND FEDERALISM PRINCIPLES}

"[T]he powers of the government are limited, and... its limits are not to be transcended.” McCulloch, 17 U.S. at 39. In keeping with this fundamental, foundational proposition, Congress may only act pursuant to an enumerated power.

See id. at 32 (the federal government "can exercise only the powers granted to it”). Appellant contends that 18 U.S.C. § 249(a)(1) violates States’ sovereignty, apparently under the theory that hate crimes are the province of State police powers and are adequately addressed by way of State laws. This argument may be quickly disposed of.

First, as noted above, in enacting 18 U.S.C. § 249(a)(1), Congress was acting pursuant to an enumerated power. Its authority for passing this statutory provision is grounded in the Thirteenth Amendment, does not spring from a

${ }^{4}$ Amici find it unnecessary to address Appellant's claim that 18 U.S.C. $\S$ 249(a)(1) unconstitutionally gives unlimited authority to the federal government to regulate hate crimes, because this argument contains no citation to any legal authority. See Appellant's Br. at 30-32. That said, it is ironic that Appellant challenges the certification requirement as granting unrestrained power to the government when it seems designed to add a layer of review -- a high-level layer at that -- to the prosecutorial process. 
“federal police power," and therefore does not, by definition, encroach on States' police power. Nor is State sovereignty, as codified in the Tenth Amendment, implicated because Section 249(a)(1) does not "commandeer" the States. See United States v. Hampshire, 95 F.3d 999, 1004 (10th Cir. 1996), cert. denied, 519 U.S. 1084 (1997).

Second, whatever may be said of States' prosecution of hate crimes, Appellant's inquiry into the necessity of Section 249(a)(1) is a policy judgment reserved to the elected branches of government and the people. Further, Appellant's support for this second-guessing are cases -- United States v. Lopez, 514 U.S. 549 (1995), and United States v. Comstock, 560 U.S. , 130 S.Ct. 1949 (2010) -- that speak to other enumerated powers -- the Commerce Clause and the Necessary and Proper Clause -- and that the Supreme Court has not directly applied to the Thirteenth Amendment context.

Third, as noted above, the concerns for States that undergirded the City of Boerne opinion are not present here. See Section II.B., infra.

Consequently, nothing in Section 249(a)(1) can be read, under Supreme Court precedent, to suggest that the statutory provision infringes on States' police powers or States' sovereignty. 


\section{AS THE THIRTEENTH AMENDMENT APPLIES TO ALL BADGES AND INCIDENTS OF SLAVERY INFLICTED UPON ANY PERSON OF ANY RACE, 18 U.S.C. § 249(A)(1) DOES NOT IMPLICATE STRICT SCRUTINY OR VIOLATE EQUAL PROTECTION}

The Thirteenth Amendment's Framers undoubtedly intended the Amendment to end chattel slavery and to eliminate the lingering vestiges of the institution of slavery. Because African-Americans were the principal racial group subject to institutionalized chattel slavery, and because African-Americans therefore most directly suffered the badges and incidents of slavery, it is often incorrectly assumed that the Congress's power to prohibit contemporary badges and incidents of slavery is limited to those conditions affecting African-Americans. However, "[t]his instinctive reaction that the badges and incidents of slavery analysis is limited to African-Americans is based upon a misunderstanding.” William M. Carter, Jr., The Thirteenth Amendment, Interest Convergence, and the Badges and Incidents of Slavery, 71 MD. L. REV. 21, 36 (2012). Although AfricanAmericans were the direct victims of slavery, the Thirteenth Amendment's Framers viewed slavery as inflicting systemic harms extending beyond its individual victims. Section Two of the Thirteenth Amendment was therefore intended to grant Congress the power to redress any badges and incidents of slavery, in whatever form they might be found. Thus, as explained in this Section, Appellant's contention that Congress's power to eliminate the badges and incidents 
of slavery only applies to African-Americans is profoundly mistaken as a matter of the Thirteenth Amendment's history, intent, and context.

Appellant argues that "while there may have been instances in which whites were subjected to involuntary servitude, whites were the primary beneficiaries of the institution of chattel slavery that the Thirteenth Amendment was intended to eradicate.” Appellant’s Br. at 50. Therefore, Appellant argues, “Congress’s Thirteenth Amendment authority to eliminate the badges and incidents of slavery does not empower it to protect persons not burdened by the badges and incidents of slavery (i.e., whites) from racially motivated crimes.” Id.

This argument wrongly assumes that the groups or individuals burdened by the contemporary badges and incidents of slavery must be perfectly coextensive with the racial group that was subject to historical chattel slavery in order for Congress to properly exercise its Thirteenth Amendment power. This argument misconstrues the nature of the badges and incidents of slavery that Congress has the power to prohibit. The Thirteenth Amendment was intended to "remove[] every vestige of African slavery from the American Republic.” CONG. GLOBE, 38TH CONG., 2ND SESS. 154, 155 (1865) (statement of Rep. Davis). Senator Charles Sumner, one of the primary architects of the Thirteenth Amendment, stated that the Amendment:

abolishes slavery entirely .... It abolishes its root and branch. It abolishes it in the general and the particular. It abolishes it in length 
and breadth and then in every detail.... Any other interpretation belittles the great amendment and allows slavery still to linger among us in some of its insufferable pretensions.

Cong. GloBE, 42ND Cong., 2ND SESS. 728 (1872). Senator Henry Wilson similarly stated that the Amendment was designed to "obliterate the last lingering vestiges of the slave system; its chattelizing [sic], degrading and bloody codes; its dark, malignant barbarizing spirit; all it was and is, everything connected with it or pertaining to it . . . .” Cong. GLOBE, 38Th Cong., 1st SESS. 1199, 1319, 1321, 1324 (1864).

Legal scholars and historians have long recognized that the "root and branches” of slavery extended beyond its direct effects on African-Americans. Professor William Carter, for example, has stated that the original intent of the Thirteenth Amendment's Framers supports an interpretation of the Amendment that tethers the reach of the badges and incidents of slavery power to the historical facts of slavery, but does not necessarily limited it to African-Americans. He states that:

[T]he badges and incidents of slavery prohibited by the Thirteenth Amendment [should] be defined with reference to two primary issues: (1) the connection between the class to which the plaintiff belongs and the institution of chattel slavery, and (2) the connection the complained-of injury has to that institution .... Even as to nonAfrican American persons, however, there may be particular injuries or forms of discrimination so closely tied to the structures supporting or created by the system of slavery that the plaintiff's personal link to that institution becomes less determinative. 
William M. Carter, Jr., Race, Rights, and the Thirteenth Amendment: Defining the

Badges and Incidents of Slavery, 40 U.C. DAVIS L. REV. 1311, 1366, 1369 (2007). ${ }^{5}$

Thus, "[t]he standards for legitimate congressional authority [under the Thirteenth

Amendment] should be conceived of as a sliding scale," under which both the

victim's identity and the type of discrimination at issue are taken into account.

Darrell A. H. Miller, White Cartels, the Civil Rights Act of 1866 and the History of

Jones v. Alfred H. Mayer Co., 77 Fordham L. Rev. 999, 1046 (2008). Even if the

first factor is attenuated in its connection to slavery, the strength of the second

factor may be such that the practice at issue nonetheless can be rationally

${ }^{5}$ In support of his contention that that the badges and incidents of slavery power only protects African-Americans, Appellant quotes an earlier article by Professor Carter stating that "[w]hites were never enslaved, nor do they suffer current legal or social disabilities as a result of slavery.” Appellant's Br. at 50. Taken in context, it is clear that the cited article does not support Appellant's argument for at least two reasons. First, the quoted portion appears in a larger discussion regarding whether racial profiling can be considered a badge or incident of slavery: "For example, a young white man claiming racial profiling could not logically assert that a practice of disproportionately subjecting white men to racebased criminal suspicion is a result of social attitudes tied to slavery. Whites were never enslaved, nor do they suffer current legal or social disabilities as a result of slavery.” William M. Carter, Jr., A Thirteenth Amendment Framework for Combating Racial Profiling, 39 Harv. Civil Rights-Civil LiBerties L. ReV. 17, 81 (2004). In context, it is clear that the subject under discussion was whether whites claiming racial profiling could assert that that particular practice subjected them to a badge or incident of slavery, not whether the badges and incidents of slavery power can ever be applied to discrimination against non-blacks. Second, in an earlier discussion on that same subject, the article makes clear that the question is more nuanced than whether the individual in question is "white" or "black": Rather, the pertinent inquiry is whether the form of discrimination at issue is one that arises out of the slave system, which does not necessarily require that the victim be black. See, e.g., id. at 35-36. 
considered a badge or incident of slavery. By way of example: hate crimes against African-Americans would strongly invoke both factors, since both the victim's identity and the form of discrimination were at the very core of American slavery. But, as the District Court recognized in this case, the ability to inflict violence with impunity based on a person's racial identity was so central to slavery and the social and legal structures supporting it that such violence amounts to a badge or incident of slavery even if the victim is non-black. See Beebee, 807 F.Supp.2d at 1052-53 (reviewing the historical evidence and stating that, "[i]n light of this history, this Court could not possibly find irrational Congress' identification of racially motivated violence as a badge of slavery. Rather, the history indicates that such a conclusion is ineluctable.”).

To be sure, the lingering vestiges of slavery will most often be felt by the descendents of the enslaved, i.e., African-Americans. But in describing the badges and incidents of slavery to be abolished by the Thirteenth Amendment, its Framers identified many instances of the effects of slavery reaching beyond AfricanAmericans. It is clear that the Framers believed that "[s]lavery not only undermined liberty for Americans of African descent, but also undermined liberty for whites.” Michael Kent Curtis, The Klan, the Congress, and the Court, 11 U. PA. J. Const. L. 1381, 1385 (2009). For example, in discussing some of the incidents of the slave system during the congressional debates leading to the Thirteenth 
Amendment, Representative James Ashley stated that "[s]lavery has for many years defied the government and trampled upon the National Constitution, by kidnapping, mobbing, and murdering white citizens of the United States guilty of no offense except protesting against its terrible crimes.” CONG. GLOBE, 38TH Cong., 2ND SeSS. 138, 139 (1865). Similarly, Senator James Harlan noted that "[one] incident of [slavery] is the suppression of the freedom of speech and of the press, not only among those down-trodden people themselves but among the white race. Slavery cannot exist when its merits can be freely discussed. ...” ConG. Globe, 38th Cong., 1st Sess. 1439 (1864). See also Cong. Globe, 36th Cong., 1st SESS. 1860-61 (1860) (statement of Representative John Bingham, accusing Virginia of having “ostracized the [white] friends of emancipation” through violence and intimidation because slaveholders in the South understood that "if free speech is tolerated and free labor protected by law, free labor might attain in their midst to such dignity and importance as would bring into disrepute the system of slave labor ....”). It is therefore clear that as a general proposition, Congress's power under the Thirteenth Amendment extends to any badge or incident of slavery as rationally defined by Congress and that such badges or incidents can extend to whites. See McDonald v. Sante Fe Trail Transp. Co., 427 U.S. 273, 29596 (1976) (“Unlikely as it might have appeared in 1866 that white citizens would encounter substantial racial discrimination of the sort proscribed under the [Civil 
Rights Act of 1866], . . . Congress was intent upon establishing in the federal law a broader principle than would have been necessary simply to meet the particular and immediate plight of the newly freed Negro slaves.”). ${ }^{6}$

Moreover, Appellant's argument is also flawed on the facts of this particular case. This victim in this case is a Native American man who has a developmental disability. Whether or not the Thirteenth Amendment's protections extend to "whites" in general, the victim of the hate crime in this case was (1) a member of a racial minority group who (2) has an identifiable disability. “Congressional legislation that targets acts or disabilities that resemble historic incidents of slavery and which are applied to discrete, insular, and identifiable minorities with a history of compelled service in America are [presumptively constitutional under the Thirteenth Amendment].” Miller, White Cartels, at 1046. If Congress's Thirteenth Amendment power does not extend to the power to punish those who inflict

${ }^{6}$ It is also worth noting that the Reconstruction Congresses enacted statutes that were designed to eliminate certain oppressive practices as to all persons, not only racial minorities or African-Americans in particular. See 1867 Anti-Peonage Act, Ch. 187, 14 Stat. 546 (1867) (codified as amended at 18 U.S.C. §1581 (2006) and 42 U.S.C. $\$ 1994$ (2006)) (prohibiting employment practices that subordinated workers, including, but not limited to American Indians); An Act to Protect Persons of Foreign Birth Against Forcible Constraint or Involuntary Servitude, ch. 464, 18 Stat. 251 (1874) (codified as amended at 18 U.S.C.§ 1584 (2006)) (prohibiting the practice of bringing children from Italy in large cities, isolating them, and exploiting their labor). For a discussion of these statutes and the fact that they extended protections well beyond African-Americans, see Rebecca E. Zietlow, Free At Last! Anti-Subordination and the Thirteenth Amendment, 90 B.U. L. REV. 255, 290-94 (2010). 
identity-based violence upon a person -- including literally branding the victim’s body with white supremacist symbols -- because of his identifiable membership in two minority groups with a history of subordination and forced labor, it encompasses very little indeed.

As 18 U.S.C. § 249(a)(1) covers all racial groups, it does not, as Appellant asserts, embody a racial classification and thus does not implicate the strict scrutiny standard of the Equal Protection component of the Fifth Amendment.

\section{CONCLUSION}

For the foregoing reasons, amici respectfully submit that the district court's order should be affirmed.

August 1, 2012

/S/

GEORGE BACH

1117 Stanford NE, MSC11 6070

1 University of New Mexico

Albuquerque, NM 87131

(505) 277-2146 